\title{
Using UV-C radiation and image analysis for fungus control in tomato plants
}

\section{Uso de la radiación UV-C y análisis de imágenes en el control de hongo en plantas de tomate}

\author{
Merlín A. Valencia ${ }^{2}$, Luis F. Patiño ${ }^{2}$, Jorge A. Herrera-Ramírez ${ }^{3}$, Darío A. Castañeda ${ }^{4}$, Jorge \\ A. Gómez ${ }^{1}$, Jairo C. Quijano*1 \\ 1. Facultad de Ciencias Básicas, Politécnico Colombiano Jaime Isaza Cadavid, \\ Carrera 48 No 7-151, Medellín, Colombia \\ 2. Facultad de Ciencias Agrarias, Politécnico Colombiano Jaime Isaza Cadavid, \\ Carrera 48 No 7-151, Medellín, Colombia \\ 3. Facultad de Ingeniería, Instituto Tecnológico Metropolitano (ITM), \\ Calle 73 No 76A - 354, Medellín, Colombia \\ 4. Facultad de Ciencias Agrarias, Universidad Nacional de Colombia, sede Medellín, \\ Calle 59 A $N$ 63-20 \\ ${ }^{(*)}$ E-mail: jcquijano@elpoli.edu.co
}

Received: 28/12/2016 Accepted: 05/10/2017

DOI: $10.7149 /$ OPA.50.4.49073

\begin{abstract}
:
The plant pathogenic fungi are the greatest threat to agriculture in the world; to counteract its effect synthetic chemical fungicides are used, which cause adverse effects on human health and the environment. Physical methods to control pathogens are emerging as an alternative for managing crop diseases; however, they have been little explored. Tomato (Solanum lycopersicum) is the most frequently cultivated vegetable in the world and it grows in a wide range of climates, both field and greenhouse. One of the most limiting factors for tomato production is the foliar disease known as powdery mildew. The yield and quality of the fruit can be reduced because the disease can develop rapidly and severely affected leaflets die. In this paper, the effect of UV-C (254 $\mathrm{nm})$ on the development of powdery mildew under greenhouse conditions was evaluated. The leaflets were submitted to different UV-C exposure times and with the acquisition of RGB images and image analysis the growth rate of the lesion was determined. The exposure times that did not cause visible injuries in healthy leaflets were used to measure the effect on leaflets with the disease. After natural infection, the lesion area, the number of total lesions and the growth rate with respect to the initial lesion area were determined. Comparing with non-treated leaflets, $30 \mathrm{~s}$ or $60 \mathrm{~s}$ applications of UV-C each $48 \mathrm{~h}$ for 10 days, significantly reduced powdery mildew severity on tomato leaflets. We also compared traditional growth rate determination using a caliper with a custom program based on image acquisition and analysis, reporting that the latest is a more complete system to follow accurately the disease evolution. This work is an important approach of applying light to agricultural problems noninvasively in preharvest conditions, which has been poorly explored in agriculture, and it demonstrates the application of image analysis in the study of important agricultural variables.
\end{abstract}

Key words: Powdery mildew; Image analysis; Physical management of disease

\section{RESUMEN:}

Los hongos patógenos de las plantas son la mayor amenaza para la agricultura en el mundo; Para contrarrestar su efecto se utilizan fungicidas químicos sintéticos, que causan efectos adversos sobre la salud humana y el medio ambiente. Los métodos físicos para controlar patógenos están surgiendo como una alternativa para manejar las enfermedades de los cultivos; sin embargo, han sido poco 
explorados. El tomate (Solanum lycopersicum) es el vegetal más frecuentemente cultivado en el mundo y crece en una amplia gama de climas, tanto en campo como en invernadero. Uno de los factores más limitantes para la producción de tomate es la enfermedad foliar conocida como mildeo polvoso. El rendimiento y la calidad del fruto pueden reducirse debido a que la enfermedad puede desarrollarse rápidamente y los folíolos gravemente afectados mueren. En este trabajo, se evaluó el efecto de UV-C $(254 \mathrm{~nm})$ sobre el desarrollo del mildeo polvoso en condiciones de invernadero. Los folíolos se sometieron a diferentes tiempos de exposición de UV-C y con la adquisición de imágenes RGB y el análisis de imágenes se determinó la tasa de crecimiento de la lesión. Los tiempos de exposición que no causaron lesiones visibles en folíolos sanos, se utilizaron para medir el efecto sobre folíolos con la enfermedad. Después de la infección natural, se determinó el área de la lesión, el número total de lesiones y la tasa de crecimiento con respecto al área inicial de la lesión. Comparando con foliolos no tratados, aplicaciones de 30 s o 60 s de UV-C cada 48 h por 10 días, redujo significativamente la severidad del mildeo polvoso en los folíolos de tomate. También comparamos la determinación tradicional de la tasa de crecimiento utilizando un calibrador con un programa personalizado basado en la adquisición y análisis de imágenes, indica que el último es un sistema más completo para seguir con precisión la evolución de la enfermedad. Este trabajo es un enfoque importante para aplicar la luz a los problemas agrícolas de manera no invasiva en condiciones de precosecha de plantas, lo cual ha sido pobremente explorado, y demuestra la aplicación del análisis de imágenes en el estudio de variables agrícolas importantes.

Palabras clave: Mildeo polvoso; Análisis de imágenes; Control físico de enfermedades.

\section{REFERENCES AND LINKS / REFERENCIAS Y ENLACES}

[1] R. Yin, T. Dai, P. Avci, A. E. S. Jorge, W. C. de Melo, D. Vecchio, Y.-Y. Huang, A. Gupta, and M. R. Hamblin, "Light based anti-infectives: ultraviolet C irradiation, photodynamic therapy, blue light, and beyond", Curr. Opin. Pharmacol. 13, 731-762 (2013).

[2] E. Levetin, R. Shaughnessy, C. A. Rogers, and R. Scheir, "Effectiveness of Germicidal UV Radiation for Reducing Fungal Contamination within Air-Handling Units", Appl. Environ. Microbiol. 67, 3712-3715 (2001).

[3] B. M. Sutherland, "Action spectroscopy in complex organisms: potentials and pitfalls in predicting the impact of increased environmental UVB", J. Photochem. Photobiol. B Biol. 31, 29-34 (1995).

[4] G. J. S. Jenkins, B. Burlinson, and J. M. Parry, "The polymerase inhibition assay: A methodology for the identification of DNA-damaging agents", Mol. Carcinog. 27, 289-297 (2000).

[5] I. S. Booij-James, S. K. Dube, M. A. K. Jansen, M. Edelman, and A. K. Mattoo, "Ultraviolet-B Radiation Impacts Light-Mediated Turnover of the Photosystem II Reaction Center Heterodimer in Arabidopsis Mutants Altered in Phenolic Metabolism", Plant Physiol. 124, 1275-1284 (2000).

[6] M. Heijde and R. Ulm, "UV-B photoreceptor-mediated signalling in plants", Trends Plant Sci. 17, 230237 (2012).

[7] P. Narayanasamy, Postharvest Pathogens and Disease Management, John Wiley \& Sons, Inc., Hoboken, NJ, USA, (2005).

[8] G. Romanazzi, A. Lichter, F. M. Gabler, and J. L. Smilanick, "Recent advances on the use of natural and safe alternatives to conventional methods to control postharvest gray mold of table grapes", Postharvest Biol. Technol. 63, 141-147 (2012).

[9] A. I. Darras, I. Bali, and E. Argyropoulou, "Disease resistance and growth responses in Pelargonium $\times$ hortorum plants to brief pulses of UV-C irradiation", Sci. Hortic. (Amsterdam). 181, 95101 (2015).

[10] C. Ouhibi, H. Attia, P. Nicot, F. Lecompte, V. Vidal, M. Lachaâl, L. URBAN, and J. Aarrouf, "Effects of nitrogen supply and of UV-C irradiation on the susceptibility of Lactuca sativa L to Botrytis cinerea and Sclerotinia minor", Plant Soil 393, 35-46 (2015).

[11] S. Klärner, B. Flemming, and B. Berkelmann-Löhnertz, "Studies on mould prevention in viticulture by means of UV-C application of vines (Vitis vinifera L.)", Landtechnik 70, 139-149 (2015).

[12] FAO, "El tomate ocupa en el mundo casi cinco millones de hectáreas", Hortoinfo.es (2014).

[13] G. Agrios, Plant Pathology, Elsevier B.V., Burlington, MA, (2005). 
[14] W. B. Jones, "Source of Inoculum, Yield, and Quality of Tomato as Affected by Leveillula taurica", Plant Dis. 71, 266 (1987).

[15] L. Kiss, R. T. a. Cook, G. S. Saenz, J. H. Cunnington, S. Takamatsu, I. Pascoe, M. Bardin, P. C. Nicot, Y. Sato, and A. Y. Rossman, "Identification of two powdery mildew fungi, Oidium neolycopersici sp. nov. and O. lycopersici, infecting tomato in different parts of the world", Mycol. Res. 105, 684-697 (2001).

[16] J. Correll, T. Gordon, and V. Elliott, "Powdery mildew of tomato: The effect of planting date and triadimefon on disease onset, progress, incidence, and severity.", Phytopathology 78, 512-519 (1988).

[17] J. Palti, "TheLeveillula mildews", Bot. Rev. 54, 423-535 (1988).

[18] M. Brand, Y. Messika, Y. Elad, D. Rav David, and A. Sztejnberg, "Spray treatments combined with climate modification for the management of Leveillula taurica in sweet pepper", Eur. J. Plant Pathol. 124, 309-329 (2009).

[19] P. Kromann, W. G. Pérez, A. Taipe, E. Schulte-Geldermann, B. P. Sharma, J. L. Andrade-Piedra, and G. A. Forbes, "Use of Phosphonate to Manage Foliar Potato Late Blight in Developing Countries", Plant Dis. 96, 1008-1015 (2012).

[20] W. Hollomon and E. Wheeler, "Controlling powdery mildews with chemistry", Powdery Mildews A Compr. Treatise 249-255 (2002).

[21] L. Kiss, "A review of fungal antagonists of powdery mildews and their potential as biocontrol agents", Pest Manag. Sci. 59, 475-483 (2003).

[22] R. R. Bélanger and C. Labbé, "Control of powdery mildews without chemicals: prophylactic and biological alternatives for horticultural crops", Powdery Mildews A Compr. TreatiseThe powdery mildews a Compr. treatise 256-267 (2002).

[23] A. Suthaparan, A. Stensvand, K. A. Solhaug, S. Torre, K. H. Telfer, A. K. Ruud, L. M. Mortensen, D. M. Gadoury, R. C. Seem, and H. R. Gislerød, "Suppression of Cucumber Powdery Mildew by Supplemental UV-B Radiation in Greenhouses Can be Augmented or Reduced by Background Radiation Quality", Plant Dis. 98, 1349-1357 (2014).

[24] A. Suthaparan, A. Stensvand, K. A. Solhaug, S. Torre, L. M. Mortensen, D. M. Gadoury, R. C. Seem, and H. R. Gislerød, "Suppression of Powdery Mildew (Podosphaera pannosa ) in Greenhouse Roses by Brief Exposure to Supplemental UV-B radiation", Plant Dis. 96, 1653-1660 (2012).

[25] W. Van Hemelrijck, S. Van Laer, S. Hoekstra, A. Aiking, and P. Creemers, "UV-c radiation as an alternative tool to control powdery mildew on apple and strawberry.", Proc. Eco-fruit Conf. 99-105 (2010).

[26] A. Suthaparan, K. A. Solhaug, N. Bjugstad, H. R. Gislerød, D. M. Gadoury, and A. Stensvand, "Suppression of Powdery Mildews by UV-B: Application Frequency and Timing, Dose, Reflectance, and Automation", Plant Dis. 100, 1643-1650 (2016).

[27] I. M. Scotford and P. C. H. Miller, "Applications of Spectral Reflectance Techniques in Northern European Cereal Production: A Review", Biosyst. Eng. 90, 235-250 (2005).

[28] L. M. Romualdo, P. H. C. Luz, F. F. S. Devechio, M. a. Marin, A. M. G. Zúñiga, O. M. Bruno, and V. R. Herling, "Use of artificial vision techniques for diagnostic of nitrogen nutritional status in maize plants", Comput. Electron. Agric. 104, 63-70 (2014).

[29] E. Saldaña, R. Siche, M. Luján, and R. Quevedo, "Review: computer vision applied to the inspection and quality control of fruits and vegetables", Brazilian J. Food Technol. 16, 254-272 (2013).

[30] J. G. Barbedo, "Digital image processing techniques for detecting, quantifying and classifying plant diseases.", Springerplus 2, 660-671 (2013).

[31] C. H. Bock, G. H. Poole, P. E. Parker, and T. R. Gottwald, "Plant Disease Severity Estimated Visually, by Digital Photography and Image Analysis, and by Hyperspectral Imaging", CRC. Crit. Rev. Plant Sci. 29, 59-107 (2010).

[32] D. A. Costa Lage, W. A. Marouelli, H. da S. S. Duarte, and A. C. Café-Filho, "Standard area diagrams for assessment of powdery mildew severity on tomato leaves and leaflets", Crop Prot. 67, 26-34 (2015).

[33] L. V Madden and G. Hughes, The Study of Plant Disease Epidemics, APS Press, St. Paul, MN, (2007).

[34] F. W. Nutter, Jr., "Assessing the Accuracy, Intra-rater Repeatability, and Inter-rater Reliability of Disease Assessment Systems", Phytopathology 83, 806 (1993).

[35] A. Reis, L. S. Boiteux, M. L. Paz-lima, P. P. Silva, and C. A. Lopes, "New hosts of Oidiopsis haplophylli in 
the Solanaceae Family in Brazil", Mycol. Res. 195-198 (2005).

[36] R. T. Sherwood, "Weibull distribution of lesion size in the stagonospora leaf-spot of orchardgrass", Phytopathology 77, 715-717 (1987).

[37] K. M. Sigulas, R. R. Hill, and J. E. Ayers, "Genetic analysis of exserohilum turcicum lesion expansion on corn", Phytopathology 78, 149-153 (1988).

[38] L. A. Furman, N. Lalancette, and J. F. White, "Peach rusty spot epidemics: Temporal analysis and relationship to fruit growth", Plant Dis. 87, 366-374 (2003).

[39] E. A. Moya, L. R. Barrales, and G. E. Apablaza, "Assessment of the disease severity of squash powdery mildew through visual analysis, digital image analysis and validation of these methodologies", Crop Prot. 24, 785-789 (2005).

[40] J. Castaño Monsalve, J. G. Ramírez Gil, L. F. Patiño Hoyos, and J. G. Morales Osorio, "Alternativa para el manejo de Phytophthora infestans (Mont.) de Bary en Solanum betaceum Cav. mediante inductores de resistencia", Rev. Protección Veg. 204-212 (2015).

[41] H. R. Kang, Computational Color Technology, SPIE Press, Bellingham, (2006).

[42] G. Sharma, W. Wu, and E. N. Dalal, "The CIEDE2000 color-difference formula: Implementation notes, supplementary test data, and mathematical observations", Color Res. Appl. 30, 21-30 (2005).

[43] A. C. Kneuttinger, G. Kashiwazaki, S. Prill, K. Heil, M. Müller, and T. Carell, "Formation and Direct Repair of UV-induced Dimeric DNA Pyrimidine Lesions", Photochem. Photobiol. 90, 1-14 (2014).

[44] M. J. Dagley, I. E. Gentle, T. H. Beilharz, F. A. Pettolino, J. T. Djordjevic, T. L. Lo, N. Uwamahoro, T. Rupasinghe, D. L. Tull, M. McConville, C. Beaurepaire, A. Nantel, T. Lithgow, A. P. Mitchell, and A. Traven, "Cell wall integrity is linked to mitochondria and phospholipid homeostasis in Candida albicans through the activity of the post-transcriptional regulator Ccr4-Pop2", Mol. Microbiol. 79, 968-989 (2011).

[45] A. Suthaparan, K. A. Solhaug, N. Bjugstad, H. R. Gislerød, D. M. Gadoury, and A. Stensvand, "Suppression of Powdery Mildews by UV-B: Application Frequency and Timing, Dose, Reflectance, and Automation", Plant Dis. 100, 1643-1650 (2016).

[46] D. Marquenie, "Inactivation of conidia of Botrytis cinerea and Monilinia fructigena using UV-C and heat treatment", Int. J. Food Microbiol. 74, 27-35 (2002).

[47] J. Liu, C. Stevens, V. A. Khan, J. Y. Lu, C. L. Wilson, O. Adeyeye, M. K. Kabwe, P. L. Pusey, E. Chalutz, T. Sultana, and S. Droby, "Application of ultraviolet-C light on storage rots and ripening of tomatoes", J. Food Prot. 56, 868-872 (1993).

[48] R. Porat, A. Lers, S. Dori, L. Cohen, B. Weiss, A. Daus, C. Wilson, and S. Droby, "Induction of Chitinase and $\beta$-1,3-Endoglucanase Proteins by UV Irradiation and Wounding in Grapefruit Peel Tissue", Phytoparasitica 27, 233-238 (1999).

[49] M. C. Canale, E. A. Benato, P. Cia, M. L. Haddad, and S. F. Pascholati, "In vitro effect of UV-C irradiation on Guignardia citricarpa and on postharvest control of citrus black spot", Trop. Plant Pathol. 36, 356361 (2011).

[50] S. L. Sukanya and 0. Spring, "Influence of temperature and ultra-violet light on viability and infectivity of Peronospora tabacina sporangia", Crop Prot. 51, 14-18 (2013).

[51] S. J. L. Mintoff, J. E. Rookes, and D. M. Cahill, "Sub-lethal UV-C radiation induces callose, hydrogen peroxide and defence-related gene expression in Arabidopsis thaliana", Plant Biol. 17, 703-711 (2015).

[52] H. L. Park, S.-W. Lee, K.-H. Jung, T.-R. Hahn, and M.-H. Cho, "Transcriptomic analysis of UV-treated rice leaves reveals UV-induced phytoalexin biosynthetic pathways and their regulatory networks in rice", Phytochemistry 96, 57-71 (2013).

[53] H. Nilsson, "Remote Sensing and Image Analysis in Plant Pathology", Can. J. Plant Pathol. 489-527 (1995).

[54] X. Cao, Y. Luo, Y. Zhou, X. Duan, and D. Cheng, "Detection of powdery mildew in two winter wheat cultivars using canopy hyperspectral reflectance", Crop Prot. 45, 124-131 (2013).

[55] C. H. Bock, P. E. Parker, A. Z. Cook, and T. R. Gottwald, "Visual Rating and the Use of Image Analysis for Assessing Different Symptoms of Citrus Canker on Grapefruit Leaves", Plant Dis. 92, 530-541 (2008). 


\section{Introduction}

Physical methods such as electromagnetic radiation can be an alternative in the management of plant diseases, due to the direct effect on the pathogens or to the indirect effect through induction of plant defenses. It is known that UV-C radiation $(200-280 \mathrm{~nm})$ has a germicidal action on microorganisms in water, on surfaces and in air [1,2]. UV can induce mutations or kill organisms once absorbed by DNA [3,4]. Oxidative effects and genetic alterations in plants could cause negative effects on plant growth [5]; however, depending on dose and wavelength, UV can act as a signal for regulation of growth, development and defense responses in higher plants [6]. UV-C has been used in agriculture, mainly for reducing postharvest diseases [7,8]. Physical methods such as UV-C treatments are an environmental friendly strategy for controlling plant diseases since it leaves no residues. Nevertheless, there is few information about its use in greenhouse or field conditions [9-11].

Tomato (Solanum lycopersicum L.) is the most frequently cultivated vegetable in the world, with more than 161 million tons produced per year [12]. However, diseases are one of the major factors limiting tomato production worldwide [13]. Tomato crop yield losses may reach $31 \%$ by powdery mildew [14]. The fungi Oidium neolycopersici Kiss or Leveillula taurica (Lev.) Arnaud are the most causal agents of this disease $[15,16]$. Under favorable conditions for the fungi, a rapid increase of a foliar lesion is caused, reducing photosynthetic activity of the plant [17]. Traditionally, this disease is chemically controlled by fungicides [18], which causes negative effects on the environment [19] and increases cost of production due to fungicide resistance in fungal populations [20]. Other alternatives, like biological or by means of systemic acquired resistance (SAR) have been researched [21,22]. Tomato powdery mildew is constantly in pressing need for new alternatives to measure and manage disease for reducing negative effects on growers, consumers and the environment due to conventional disease management. Previous studies have shown the potential of UV in controlling severity and sporulation of a number of different powdery mildews [23,24], and indicate that UV may be used as a powerful strategy in management of these economically important diseases. For example, the application of UV-B irradiance with a broad spectrum UV source significantly reduced powdery mildew severity in roses [24] and cucumber [23]. Studies with UV-C on powdery mildews in preharvest systems are few; a reduction of the disease on apple and strawberry comparable with specific fungicide treatments in field conditions was obtained with a UV-C [25], while $280 \mathrm{~nm}$ was the optimal wavelength for controlling tomato powdery mildew in in vitro trials [26].

Optical techniques such as image analysis proved to be an effective tool in various fields and applications. Agriculture is one of these fields and nowadays it has become more than a way to feed people; it intervenes in energy production and several other industrial applications. Technological developments have had a great impact in its expansion and progress, but there still exist room for scientific and technical improvements. In agriculture, the study of changes in optical properties in relation to the severity of the diseases has been developed applying spectral reflectance techniques for cereal production including crop protection and weed control [27]. On the other hand, parameters like canopy, yield, product quality, and diseases characterization are important measurements from the farmer's point of view, where image acquisition and analysis are especially useful. These techniques have helped in characterization of plants and fruits as well as to implement sorting techniques, due to rapid processing, non-physical contact with the specimens and its low cost [28,29]. Some diseases do not have any visible symptoms associated, in those cases; usually some sort of complex evaluation is necessary. However, most diseases exhibit some type of indication visible for humans and hence they are susceptible to be captured using commercial or industrial cameras [28,30]. Trained raters may be also efficient in recognizing and quantifying diseases, but this approach have some disadvantages. The main disadvantages are the necessity of training, high variability in assessment, and decrease in accuracy because of tiring and concentration loss [31]. These visual disease assessments rely on estimates of percent of leaf area covered by lesions. One typical strategy to increase accuracy and reliability from raters when assessing severity of damage is the use of standard area diagrams (SADs) [31-34]. These SADs have to be developed for each disease and they help raters to compare and evaluate the problems using SADs as scale of reference. But SADs implicitly have some inaccuracy involved due to the fact that severity of lesions is classified in percentage ranges, not absolute values. By the use of digital images and depending on the application, some of the mentioned problems can be reduced or even eliminated. Typical visual disease assessments rely on estimates of percent of leaf area covered by lesions that can be performed measuring the area of the leaves that are affected by the disease using calibrated systems of image acquisition [28]. Since lesions could be small, 
accurate estimates of lesions are difficult to make only visually. Quantification by image analysis isolates the region of interest, in order to provide an estimate for the severity of the disease. Thus, image-based phenotyping can greatly enhance the data available for characterizing plant disease.

The aim of this research was to study the effects of the UV-C light in order to control the fungal infection by powdery mildew on tomato leaflets. The experiments were implemented using commercially available elements for the UV-C lamp and the camera to acquire RGB images of the samples. Using image analysis, by means of a custom developed computational program, the severity of the disease was evaluated. The results show that the advance of the fungus infection was efficiently reduced by using UV-C radiation treatments. This study goes hand in hand with the latest trends in the area of sustainable farming, development of photonics methods in the applications of new technologies and higher precision data acquisition that can reduce the environmental impact of conventional technologies.

\section{Material and Methods}

\section{2.a Plant production}

Tomato cv. 'Chonto' plants, highly susceptible to Powdery mildew, were grown in greenhouse conditions and were irrigated with a Hogland nutritive solution every week in an aeroponic system.

\section{2.b Application of UV-C}

The UV-C light was produced by a commercial UV Source Sylvania ${ }^{\circledR}(0.6 \mathrm{~m}$ long and $0.04 \mathrm{~m}$ wide). The lamp has a characteristic spectral emission over the UV-C region with a specific wavelength of $254 \mathrm{~nm}$, typically encountered in low pressure germicidal lamps, according to manufacturer's specifications. For experiments, the UV-C lamp was housed in a wooden stand, wrapped in aluminum for easy handling and operator protection during irradiation. To have fully developed and physiologically active leaflets, plants of thirty days old were used. Irradiations with the UV-C lamp were performed on branches located in the middle third of the plant and the UV-C was applied on the adaxial side of leaflets with the lamp 0.1 meters parallel to the branch. We first established exposure times that did not cause phototoxicity in the plant. Then, we proceed to perform UV-C treatments in leaflets with the disease. The UV-C light was directed to an early state of powdery mildew defined as a lesion of approximately $0.2 \mathrm{~cm} 2$ in area, expressed under natural conditions of the disease. Eight infected tomato leaflets from eight different plants were irradiated (with 30 or 60 seconds) every 48 hours for 10 days.

\section{2.c Characterizing UV-C effect on the disease}

In tomato plants, symptoms are initiated by small chlorotic lesions that turn yellowish and become visible on surface of the leaflet, which corresponds with the colonization of the fungus [35]. The growth of the lesion caused by the disease was measured calculating the growth rate of the lesion area through 10 days. The area of the lesion was determined classically [36-40] measuring the diameter of lesion with a caliper and assuming a circle-shaped lesion.

We also acquired RGB images of the leaves in order to digitally measure the area of the lesions. We implemented a custom segmentation program in Matlab® platform that allowed us to estimate lesion area in an automatic way and more accurately than using the classical approach using a caliper. Fig. 1 shows a snapshot of the program interface. The interface contains a screen to load and display the images, allowing the user to select one or several points that belong to the area of interest (i.e points outside the affected area or point inside of the lesion area). The program obtains the $\mathrm{L}^{*} \mathrm{a}^{*} \mathrm{~b}^{*}$ color values from the RGB images based on the calculations proposed in Kang [41]. With the $\mathrm{L}^{*} \mathrm{a}^{*} \mathrm{~b}^{*}$ color values the program calculates color differences (using CIEDE2000 formula [42]) with respect to mean color values of the previously selected points. Therefore, we defined a threshold value that allows the proper segmentation of the zone of interest. Fig. 1A shows the results of the area calculations in pixels and a text box that allows the conversion of pixels to metric scale (The relation between pixel size and metric units is obtained by using a reference line with known length over the background of the images). The bottom part of the Fig. 1 shows a typical segmentation result of the unaffected area and the segmentation of the lesion region in a tomato leaflet. 


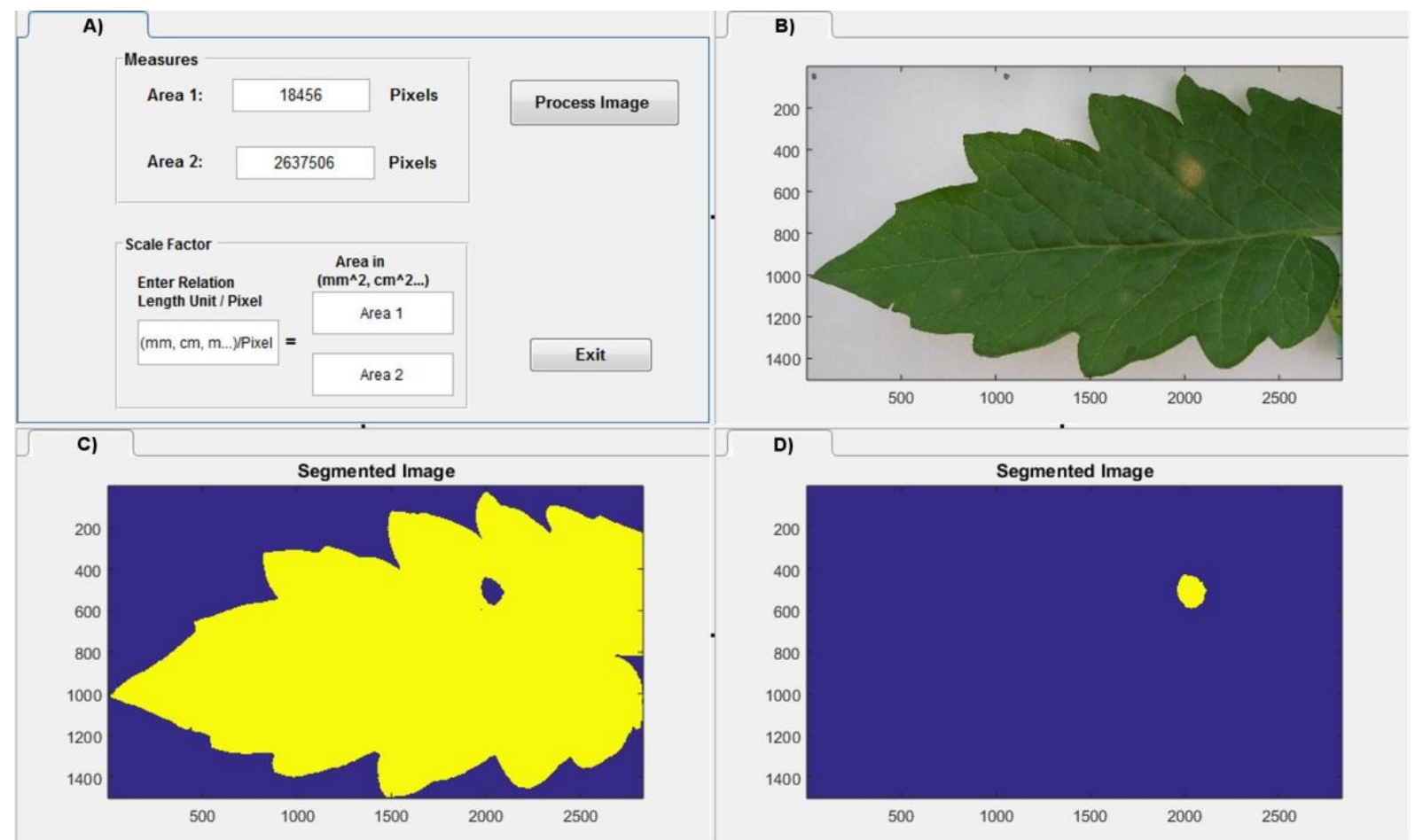

Fig. 1. Program interface for unaffected and lesion area calculation implemented in Matlab®. A) Area calculation frame. B) Image uploading frame. C) Segmentation image of the unaffected leaflet area. D) Segmentation image of the lesion area.

\section{2.d Characterizing the UV-C effect on Fungus}

To understand the direct effect of the UV-C exposure times on fungus, conidia from eight to ten-day-old colonies of fungus (expressed on the leaflets), were deposited on the surface of water agar (3\%) in $3.5 \mathrm{~cm}$ diameter Petri dishes by gently touching the diseased leaves to the agar surface. Immediately after conidial deposition, Petri dishes (without lids) containing conidia were exposed to the above mentioned UV treatments. After UV exposure, the Petri dishes were sealed and incubated at $22{ }^{\circ} \mathrm{C}$ in complete darkness. Thirty six hours after the start of the experiments, Conidia within 9 regions of interest per treatment were examined with a light microscope (200X). Conidia with clearly visible germ tubes were considered as germinated [26], and three repetitions were performed.

\section{2.e Statistical analysis}

A Complety random design, with 2 treatments and 8 repetitions (one leaflet per plant), was used. Means were compared using Tukey's multiple range tests. The data analysis was performed in R program ${ }^{\circledR}$ (version 3.0.1, 2013). Experiments were two times repeated.

\section{Results}

\section{3.a Effect of the application of UV-C treatment on leaflets with the disease}

Firstly, healthy leaflets were exposed to 4 different UV-C treatments, 30, 60, 90 and 120 s. UV-C exposure times of $90 \mathrm{~s}$ and $120 \mathrm{~s}$ caused phototoxicity based on the apparition of necrotic lesions and disruption of foliar tissue, being $120 \mathrm{~s}$ the exposure time that harm the leaflets the most. On the other hand, exposure times of 30 and $60 \mathrm{~s}$ did not induced any damaged regions on the leaflet after 10 days (data no shown); therefore these exposure times were chosen for measuring the effect of UV-C on powdery mildew by classical and images methods. According to this, exposure of tomato plants having an initial lesion of the disease to UV-C reduced severely the proliferation of powdery mildew compared with non-exposed control plants $(P<0.01)$ (Fig. 2A). This result indicates that UV-C treatments stopped the further evolution of the disease defined as an increase of number of lesions, with 2.13 and 1.1 lesions per leaflet at the end of evaluation for $30 \mathrm{~s}$ and $60 \mathrm{~s}$, respectively, while 7.0 lesions was observed in non-exposed plants (Fig. 2A). Fig. 2B shows the growth rate (defined as: (Final area-Initial area)/Initial area) measuring the areas with a caliper. The disease in the leaflet was highly controlled for $30 \mathrm{~s}$ and $60 \mathrm{~s}$ augmenting its initial size 
just 0.9 and 0 times, respectively $(P<0.01)$, whereas in control plants the initial size of the lesion augmented 6.22 times.

A)

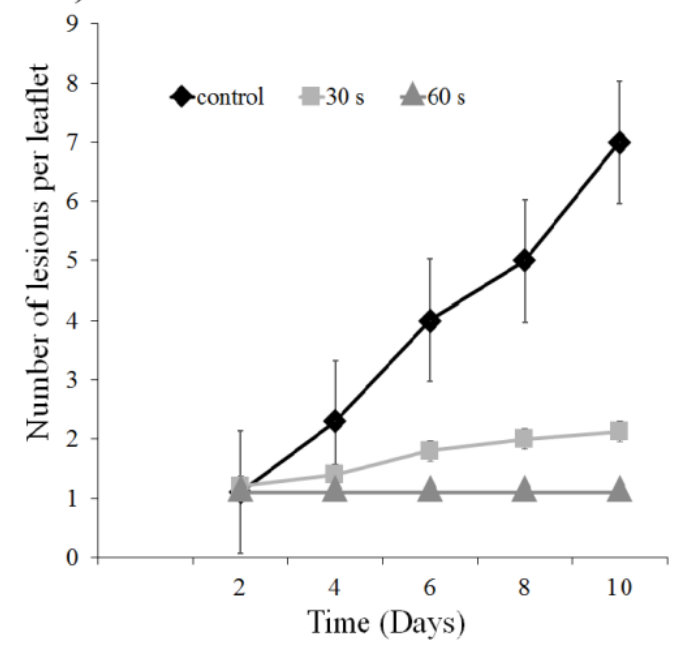

B)

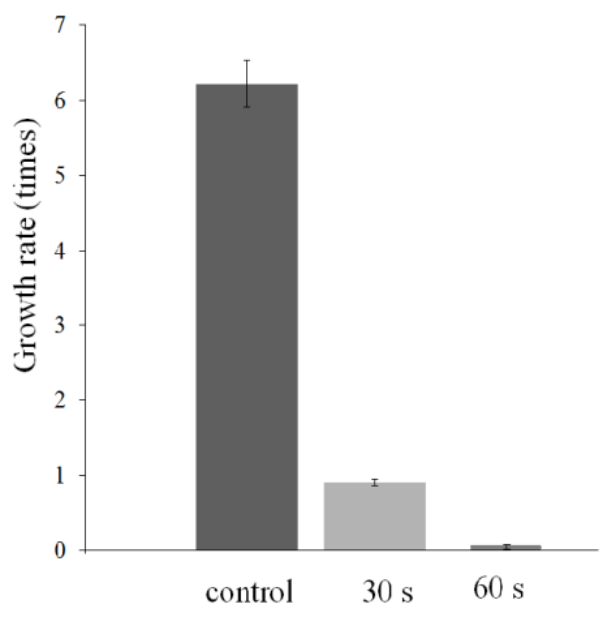

Fig. 2. Biological effect of $30 \mathrm{~s}$ and $60 \mathrm{~s}$ applications of UV-C, each $48 \mathrm{~h}$ for 10 days, on early lesion of Powdery mildew of tomato under natural infection within greenhouse conditions. A) Total number of lesions of Powdery mildew per leaflet. B) Growth rate of

lesion by Powdery mildew at the last day of evaluation measured with a caliper. $(\mathrm{P}<0.01), \mathrm{n}=8$, mean \pm standard error.

One of the important features of the image analysis is that it allows the comparison of the lesion area with the total area of the leaflet easily. Fig 3A shows the foliar affected area, by means of the percentage of the leaflet harmed by the disease. In the control case, $8.5 \%$ of the leaflet is affected by the disease while only $0.9 \%$ y $0.4 \%$ of the leaflet is affected by the disease after five UV-C exposures of 30s and 60 s, respectively.

The growth rates calculated from the areas measured by the image analysis approach are depicted in Fig. 3B, with an aument of 1.0 and 0 times with respect to the initial size of the lesion for $30 \mathrm{~s}$ and $60 \mathrm{~s}$, respectively; while the control showed an increase of 8.7 times. Both conventional methods using caliber (Fig. 2B) and image analysis (Fig. 3B) for measuring the quantity of the disease showed similar results $(P<$ 0.01 ), however, a higher disease was observed when image analysis was used. Both UV-C exposure times $30 \mathrm{~s}$ and $60 \mathrm{~s}$ were equally effective in controlling the disease, but UV-C application of $60 \mathrm{~s}$ fully inhibited the growth of lesion.
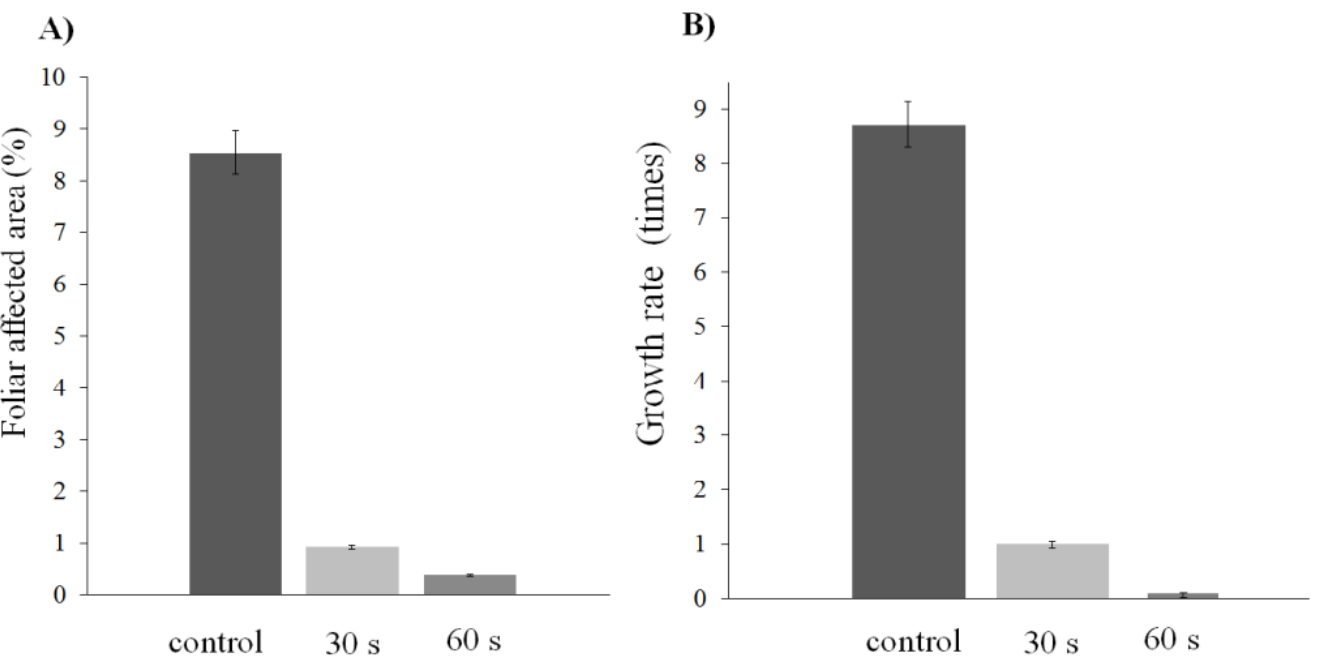

Fig. 3. Biological effect of $30 \mathrm{~s}$ and $60 \mathrm{~s}$ applications of UV-C, each $48 \mathrm{~h}$ for 10 days, on early lesion of Powdery mildew of tomato under natural infection within greenhouse conditions. A) Percentage of lesion area by Powdery mildew on tomato leaflets, measured with a custom segmentation program in Matlab® platform. B) Growth rate of the lesion cuased by Powdery mildew at the last day of evaluation measured by with a custom segmentation program in Matlab ${ }^{\circ}$ platform. $(P<0.01), n=8$, mean \pm standard error. 


\section{3.b Effect of the application of UV-C treatment on fungus germination}

Fig. 4 shows images of conidia after treatment with UV-C. A significantly reduction of germination was found after $36 \mathrm{~h}$ after one irradiation with UV-C exposure times of $30 \mathrm{~s}$ and $60 \mathrm{~s}$ on fungus conidia on water agar. The germination percentage were $2.8 \%$ and $0 \%$ for exposure times of $30 \mathrm{~s}$ and $60 \mathrm{~s}$, respectively, while in the control case the germination was $83 \%$.
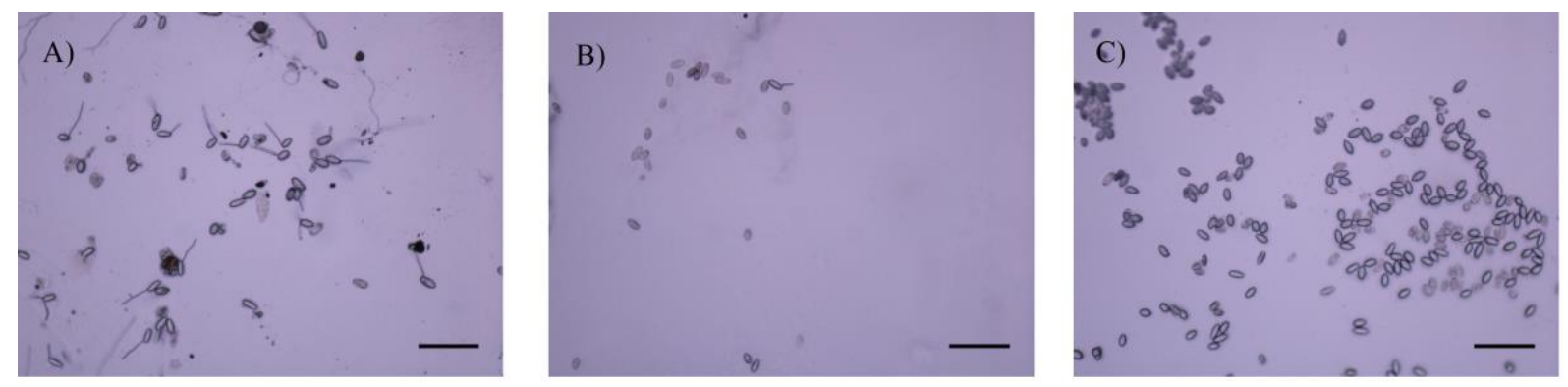

Fig. 4. Biological effect of UV-C exposure on germination percentage of fungus conidia on water agar in Petri dishes $36 \mathrm{~h}$ after incubation. 270 conidia from each treatment were assessed for visible germ tubes with a light microscope (200X). A) Germination of conidia on control case. B) Germination after 30 s exposure to UV-C. C) Germination after 60 s exposure to UV-C. Scale bar $=10 \mu \mathrm{m}$.

\section{Discussion}

The current study highlights the potential of the preharvest application of UV-C to control powdery mildew and validates image acquisition and processing as a powerful tool to assess disease severity evolution in tomato plants. In general, the data show that short exposure times of UV-C irradiation significantly reduced the growing rate of powdery mildew on greenhouse-grown tomato plants post natural infection by fungus, without negative effects on plant growth, which few times has been tested directly on whole plants, since almost all studies have been carried out on harvested plant products. Biologically, it is known that UV-C light has a direct effect on the pathogen by killing its mycelium [25], besides the absorption of high-energy UV photons by fungi DNA bases induces DNA damage provoking the conformation of dimers [43] that block the action of DNA polymerase and thereby prevent genome replication and cell cycle [4]. Inhibition of mitochondrial activity also occurs, which constrains cell wall biosynthesis, followed by impaired or reduced conidial germination [44]. The last results presented here and obtained directly on the fungus; suggest that UV-C treatment inhibited conidial germination. Previous investigations, indicated that $60 \mathrm{~s}$ of UV $(280 \mathrm{~nm})$ did not kill conidia nor completely inhibit their germinability; rather, it delayed the conidial germination processes [45]. However, in contrast, in our work, a shorter wavelength $(254 \mathrm{~nm})$ with a exposure time of $60 \mathrm{~s}$ did cause fully reduction of germination, in comparison with 12 and 24 min reported by Suthaparan et al. [45]. Furthermore, the wavelength we chose did not cause any phototoxicity symptoms in tomato leaflets. A difference of UV dose could explains these different results; since it had been demonstrated that biological effect of UV depends on dose and wavelength $[3,46]$. UV-C in vitro testing showed that one irradiation was enough to impair fully the fungus germination; however, due to polycyclic nature of the disease, a regular application over time is better than using higher dose rates with longer intervals between applications [25].

Comparing with the control, 30s or 60 s applications of UV-C, each $48 \mathrm{~h}$ for 10 days, significantly reduced powdery mildew growth rate on tomato leaflets. Until the extent of our knowledge, this result is the first achieved in preharvest condition for controlling powdery mildew on tomato plants after natural infection by the fungus. Reports of UV-C effect in agriculture, are mainly related with postharvest diseases management [8,47-50]; and the use of UV-C for controlling diseases in preharvest condition has been poorly achieved, particularly on powdery mildew diseases. Van Hemelrijck et al. [25], showed that UV-C, on apples and strawberries with powdery mildew, significantly reduced the disease without negative effects on plant performance in field conditions. In a similar study, UV-C application was used as a complementary treatment to fungicide applications to reduce significantly the disease severity of $B$. cinerea (up to $82 \%$ ), demonstrating the possibility of combining UV-C with fungicides for improving disease management [11]. The effectiveness of UV-C founded in this study, could be also supported by the fact that it is likely that the reduction of development of new lesions after UV-C treatment observed in our work could be also due to that this light can induce defense in plants [51,52]. In addition, most powdery mildews grow superficial on leaves, making them easier to be reached by UV-C light [25]. 
Another milestone feature of the current study is the use of image acquisition and processing as an approach to assess disease evolution. Traditionally, assessment of plant disease severity relies on visual inspection of plant tissue by trained raters [36-40,53], who categorize disease severity according to a discrete scale [31]. Disease symptoms often result from physiological changes that may alter the spectral pattern of the plant [54]. We have shown that image acquisition and processing offers a feasible alternative to the more classical visual assessments of disease severity evolution and quantification in plants [55]. In our work, we implemented the capture of RGB images and from them we measured the areas of lesions and areas of complete leaflets. Using image acquisition for determining these areas have proven a reliable method in other cases, but to our knowledge it has not been considered in combination with UV-C when evaluating this radiation effects over the tomato crops themselves and over the powdery mildew infecting the leaflets. One of the advantages of the digital determination of these areas is that no need for any sort of diagram development like SADs has to be made [32], in our case no comparison against this kind of reference is needed, actually as in other works [32], these measurements are considered as reference. We compared the areas measured digitally with those made manually with a caliper and assuming a round shaped lesion, fact that is a reasonable approximation, but measurements of total area of the leaflet using this manual method can be more tedious and less accurate if any geometrical shape easy to estimate the area is used.

Our approach takes advantage of the current development and ubiquity of technology in imaging and illumination to establish a scheme that provides alternatives to the conventional methods in agriculture. Overall, this approach in combination with UV-C treatment shows that photonic methods in agriculture can be helpful, reliable, safe and, in our case, of low cost due to the use of commercial parts.

\section{Conclusions}

We have demonstrated that the use of UV-C is effective in controlling powdery mildew on preharvest conditions in tomato leaflets. This study is the first to examine the effect of preharvest UV-C treatment in combination with image acquisition and processing for a precise assessment of disease evolution in greenhouse-grown tomato plants.

\section{Acknowledgements}

We are grateful to student James Pico López for his valuable contributions. This work was partially presented in the IX Reunión Iberoamericana de Óptica y XII Reunión Iberoamericana de Óptica, Láseres y Aplicaciones (RIAO/OPTILAS), Pucón, Chile. 